\title{
Evaluation Of Proximate Composition And Antinutritional Factors Of Cyperusesculentus(Tigernut) As Influenced By Boiling
}

\author{
Okorie, S.U And Nwanekezi, E. C. \\ Department Of Food Science And Technology, Imo State University, Owerri, Nigeria.
}

\begin{abstract}
Fresh Cyperusesculentus (Tigernut) Nut Were Purchased From Karaworo Market, Lokoja In Kogi State, Nigeria. The Nuts Were Processed And Used For Analysis. Fresh Nut Samples Were Divided Into Two Portions. One Portion Of The Nuts Was Cooked (Boiled) For 40mins After Which They Were Dried In An Oven And Ground Using A Moulinex Blender Into Powder. The Powder Was Packaged In A Labeled Polyethylene Bag And Kept In A Freezer $\left(20^{\circ}\right.$ c) For Analysis. The Remaining Portion (Raw) Was Directly Ground Using The Same Blender And Analyzed. The Result From The Investigation Indicated That Boiling Reduced The Proximate Composition And The Anti-Nutritional Factors In Tigernut. The Fat Content, Protein Content, Crude Content, Ash Content And Carbohydrate Reduced Significantly (P<0.05) From 12.21\%, 4.13\%, 8.13\%, 1.80\% And $33.64 \%$ To $4.53 \%, 1.53 \%, 7.79 \%, 0.142 \%$ And 23.96\% Respectively Except Moisture Content Which Increased From 50.66\% To 51.41\%. Tannin, Oxalate, Alkaloid Hydrogen Cyanide (Cn) And Saponin Reduced Considerably From $0.536 \mathrm{mg} / \mathrm{G}, 2.75 \mathrm{mg} / \mathrm{G}, 1.54 \%, 4.01 \times 10^{-3} \mathrm{mg} / \mathrm{Kg}$ And $0.594 \%$ To $0.345 \mathrm{mg} / \mathrm{G}, 2.64 \mathrm{mg} / \mathrm{G}$,

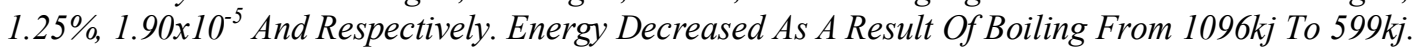

Keywords: Antinutritional Factors, Cyperusesculentus(Tigernut), Processing And Proximate Composition
\end{abstract}

\section{Introduction}

The Search For Lesser Known And Underutilized Indigenous Food Crops, Many Of Which Are Potentially Valuable As Human And Animal Foods Have Been Intensified To Maintain A Balance Between Population Growth And Agricultural Productivity Particularly In The Tropical And Subtropical Areas Of The World. Cyperusesculentus(Tigernut) Is Sedge Of The Family Cyperaceae Which Produces Rhizomes From The Base And Tubers That Are Somewhat Spherical. It Is Commonly Known As "Earth Almond", "Chufa" And "Zulu" Nuts.

In Nigeria, Three Varieties (Black Brown And Yellow) With Different Names Are Planted, But Only Two Varieties Of Yellow And Brown Are Readily Available In The Market. The Yellow Variety Is Preferred To All The Other Varieties Because Of Its Inherent Properties Like Its Bigger Size, Attractive Colour And Flesher Body. Tigernut Can Be Eaten Raw, Roasted, Dried, Baked Or Made Into Refreshing Beverage (Tigernut Milk). The Nuts Are Usually Eaten Unprepared, Pounded Into Cake And Served At The End Of A Meal (Lowe, 1973).

Medicinally, It Is Regarded As A Digestive Tonic, Having A Heating Effect On The Digestive Tonic, Having A Heating Effect On The Digestive System And Alleviating Flatulence. The Nut Is Used In The Treatment Of Boil, Cold, Polio, Ulcers (Chevalier, 1990).

Tigernut Has Been Described As An Important Food Of High Nutritional And Economic Values (Oguntona And Akinyele, 1995) And A Good Source Of Starch For Human Consumption And Industrial Use (Barko And Smart, 1979). It Yields More Milk Upon Extraction And Contains Lower Fat And More Protein (Okafor And Okolo, 2003). It Has Considerably High Levels Of Fibre, Protein, Carbohydrates Especially Natural Sugars (Soluble Glucose), Potassium And Phosphorus. The Very High Fibre Content Combined With A Delicious Taste Make It Ideal For Children, Older And Sports Men (Annon, 2005). Although, Tigernut Is Gluten And Cholesterol Free, It Is Rich In Essential Amino Acids (Lysine, Threonine And Cysteine), Oil, Oleic Acids, Vitamins C And E And Very Low In Sodium Content.

Many Studies Have Carried Out On Tigernut (Eteshola And Oraedu, 1996) But There Is Paucity Of Information On The Antinutritional Factors And Proximate Composition. The Aim Of This Study Is To Evaluate The Effect Of Boiling Of Tigernut On The Proximate Composition And Antinutritional Factors.

\section{Chemical Analysis}

Proximate Composition Analysis

The Method For Sample Analysis For Protein, Fat (Extracted By Soxhlet Apparatus), Ash, Crude Fibre, Moisture And Carbohydrate By Difference Were Carried Out According To The Standard Method Of Aoac (2005). Miffle Furnace Was Used In The Case Of Crude Fibre And Ash. Microkjeldahl Method Of Digestion And Distillation Was Used To Determine The Nitrogen Content. Crude Protein Was Obtained By 
Multiplying Percentage Nitrogen By 6.25 (Nx6.25). Energy Was Calculated Using The Awater Factor ( $4 \mathrm{x} \%$ Protein $+9 \mathrm{x} \% \mathrm{Fat}+4 \mathrm{x} \%$ Carbohyrate). All The Measurement Were Carried Out In Triplicates.

\subsection{Anti-Nutritional Factors Analysis}

The Folin- Denis Spectrophometric Method According To Pearson (1976) Was Used To Determine Tannins. The Method Described By Munro And Basir (1969) Was Used To Determine Oxalate While The Gravimetric Method Of Harbone (1973) Was Adopted For Alkaloids. The Standard Method Described By Aoac (2005) And Onwuka (2005) Was Used For Hydrogen Cyanide And Saponin Determinations.

\subsection{Statistical Analysis}

Data Obtained From The Treatment Of The Samples Were Subjected To One- Way Analysis Of Variance (Anova) And Significant Mean Were Separated Using The Duncan's Multiple Range Test (Mcdonald Et Al., 1998) Using Steel And Torrie (1980).

Table 1: Mean Proximate Composition Of Cyperusesculentus(Tigernut) As Influenced By Boiling

\begin{tabular}{lll}
$\begin{array}{c}\text { Contents } \\
(\%)\end{array}$ & Raw & Boiled \\
\hline Moisture & $50.66^{\mathrm{b}} \pm 0.008$ & $51.41^{\mathrm{a}} \pm 0.013$ \\
Fat & $12.21^{\mathrm{a}} \pm 0.013$ & $4.53^{\mathrm{b}} \pm 0.021$ \\
Crude Fibre & $8.13^{\mathrm{a}} \pm 0.020$ & $7.79^{\mathrm{a}} \pm 0.010$ \\
Protein & $4.13^{\mathrm{a}} \pm 0.021$ & $1.53^{\mathrm{b}} \pm 0.002$ \\
Ash & $1.80^{\mathrm{a}} \pm 0.016$ & $0.142^{\mathrm{a}} \pm 0.001$ \\
Carbohydrate By Difference & $33.64^{\mathrm{a}} \pm 0.00$ & $23.96^{\mathrm{b}} \pm 0.014$ \\
Energy, Kj & 1096 & 599
\end{tabular}

A,B Mean \pm S.D Values With Different Superscript Letters In A Row Are Significantly Different $(\mathrm{P}<0.05)$

Table 2: Mean Antinutritional Factors Of Cyperusesculentus(Tigernut) As Influenced By Boiling

\begin{tabular}{lcc} 
Contents & Raw & Boiled \\
\hline Tannin $(\mathrm{Mg} / \mathrm{G})$ & $0.536^{\mathrm{a}} \pm 0.006$ & $0.345^{\mathrm{b}} \pm 0.017$ \\
Oxalate $(\mathrm{Mg} / \mathrm{G})$ & $2.75^{\mathrm{a}} \pm 0.020$ & $2.64^{\mathrm{b}} \pm 0.050$ \\
Alkaloid $(\%)$ & $1.54^{\mathrm{a}} \pm 0.008$ & $1.25^{\mathrm{b}} \pm 0.013$ \\
$\begin{array}{l}\text { Hydrogen Cyanide } \\
\text { (Hen) }(\mathrm{Mg} / \mathrm{Kg})\end{array}$ & $4 \times 10^{-3 \mathrm{a}} \pm 0.000006$ & $1.93 \times 10^{-5 \mathrm{~b}} \pm 0.0001$ \\
Saponin $(\%)$ & & $0.158^{\mathrm{b}} \pm 0.00008$
\end{tabular}

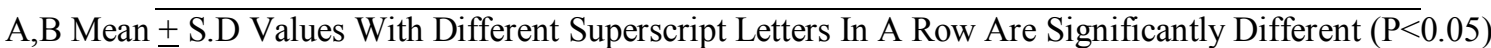

\section{Result And Discussion}

3.1 Boiling Effect On The Poximate Composition Of Tigernut (Cyperusesculentus).

The Result (Table 1) Indicated That Boiling Greatly Affected The Nutrients Analyzed. The Moisture Content Of The Tigernut (Cyperusesculentus) Samples Was Significantly Different $(\mathrm{P}<0.05)$ From Each Other. The Boiled Tigernut Sample Had A Higher (51.41\%) Moisture Content Than The Raw Sample (50.66\%). The Moisture Content Value Increased In The Sample Possibly Due To The Absorption Of Water Into Seed During Moist Cooking. Moisture Is Closely Associated With The Absorbing Macromolecules By Forces Of Absorption, Which Could Be Attributed To Vandawaal Forces Or To Hydrogen Bond Formation (Onwuka, 2005).

The Fat Contents Of The Tigernut Samples Were Significantly Different $(\mathrm{P}<0.05)$. Boiling Caused A Significant Decrease (4.53\%) In The Sample Compared To The Value Of The Raw Sample (12.21\%) In The Percentage Of Extractable Oil.

The Protein Content Of The Tigernut (Cyperusesculentus) Samples Varied Significantly $(\mathrm{P}<0.05)$. Protein Value (4.13\%) Significantly Reduced To $1.52 \%$ After Boiling. This Is In Line With The Report By 
Miroslawaet Al. (1997) That Heat Application Caused The Unzipping Of The Hydrophobic Force Leading To Partial Or Complete Disruption Of The Primary, Secondary Tertiary Or Quaternary Structure Of Protein Molecules Thereby Leading To The Protein Content Of The Boiled Sample.

The Tigernut Samples Were Samples Were Significantly Different $(\mathrm{P}<0.05)$ In Fibre Content. The Raw Tigernut Sample Had A Higher (8.13\%) Fibre Content Than The Boiled Sample (7.79\%). The Reduction Observed In The Boiled Sample Might Be Due To The Fact That Cooking Softens Cellulose, And Encourage Loss Of Indigestible Plant Components, Causing The Cells To Separate Easily And Making The Nut Easier To Digest (Cameron, 1983).

The Tigernut Samples Were Significantly Different $(\mathrm{P}<0.05)$ From Each Other In Ash Content. Analysis Showed That The Raw Tigernut Sample Had A Higher (1.8\%) Ash Content Compared To The Boiled Sample Which Had An Ash Value Of 0.142\%. The Boiled Sample Had A Significant Reduction In Its Ash Content As A Result Of The Leaching Of Mineral Elements Into The Cooking Water (Hunt Et Al., 1987).

The Carbohydrate Content Of The Tigernut Samples Were Significantly Different $(\mathrm{P}<0.05)$ From Each Other. The Raw Tigernut Had A Higher (33.64\%) Value As Compared To The Boiled Sample Which Had A Lower (23.96\%) Value. A Lower Value Was Observed In The Boiled Sample And This Could Be As A Result Of The High Moisture Content.

\subsection{Boiling Effect On Anti-Nutritional Factors Of Tigernut (Cyperusesculentus).}

Boiling Reduced The Anti-Nutritional Factors Present In Tigernut(Cyperusesculentus). From Table 2, The Raw Value $(0.5357 \mathrm{mg} / \mathrm{G})$ Of Tannin Was Significantly Reduced To $0.345 \mathrm{mg} / \mathrm{G}$ After 30mins Of Boiling. The Reduction In Tannin Was Due To The Boiling Process. Also, This Reduction Was As A Result Of Combination Properties Including Protein And Other Organic Substances Or To Alterations In Their Chemical Structure (Bamgboseet Al., 2003).

Furthermore, It Could Be Stated That The Reduction In Tannin Content Is Sequel To The Fact That Tannins Contain Polyphonic Substances Which Are Water Soluble In Nature (Kumar And Reddy, 1979) And These Substances Are Often Found In Their Seed Coats (Onwuka, 2005) Resulting In Their Leaching Out During Boiling Into The Cooking Medium Especially When The Water Is Discarded After Boiling.

The Oxalate Content Of The Tigernut Was Reduced From $2.75 \mathrm{mg} / \mathrm{G}$ To $2.64 \mathrm{mg} / \mathrm{G}$ After Boiling For $30 \mathrm{mins}$. The Oxalate Content Of The Tigernut Samples Differed Significantly $(\mathrm{P}<0.05)$ From Each Other.

Boiling Reduced The Alkaloid Content Of Tigernut ( $\mathrm{P}<0.05)$ From 1.54\% To 1.25\% After 30mins Of Boiling. The Alkaloid Content Of Tigernut Was Reduced After Boiling As A Result Of The Impact Hot Water Had On It Thereby, Leaching Out The Toxic Substances. Onwuka (2005) Indicated That Simple Boiling Removes The Alkaloids Present In Plants.

Boiling Remarkably Reduced (4.0x10 $0^{-3} \mathrm{mg} / \mathrm{Kg}$ ) Of Hydrogen Cyanide (Hcn) To $1.93 \times 10^{-5} \mathrm{mg} / \mathrm{Kg}$. This Significant Difference In These Samples $(\mathrm{P}>0.05)$ Was Due To The Leaching Out Of The Toxic Substances Into Boiling Water And This Is Related To The Report By Kay Et Al. (1977) That A Lot Of Hydrocyanic Acid Known To Inhibit The Respiratory Chain At The Cylochrome Oxidase Level Is Lost During Soaking And Cooking So That Its Content In Plants Poses No Danger Of Toxicity.

The Saponin Contents Of Tigernut Were Significantly Different $(\mathrm{P}<0.05)$. The Initial Value $(0.5949 \%)$ Was Reduced To $0.158 \%$ After 30mins Of Boiling.

\section{Conclusion}

This Study Showed That Boiling As A Processing Method Reduced The Anti-Nutritional Component Levels In Cyperusesculentuswhen Compared With The Unprocessed (Raw) Sample. It Was Also Observed From The Results That Processing Cyperusesculentusby Boiling Alone Reduced The Nutritional Component Levels Except For Moisture Which Was Increased Due To The Absorption Of Water Upon Boiling.

\section{References}

[1] Lowe, J. (1973). Nigeria Sedge. $2^{\text {nd }}$ Ed., Ibadan, Nigeria.Pp. 83- 84.

[2] Chevalier, G.E. (1990). The Nut As A Medicinal Plant. J. Agric. Sci., 17: 188 - 201.

[3] Oguntona, E. B. And Akinyele, I. O. (1995). Nutrient Composition Of Commonly Eaten Food In Nigeria.Food Basket Foundation Publication Series.Obt Printing Ventures, Ibadan.Oyo State.

[4] Barko, J.W And Smart, R.M. (1979). The Nutritional Ecology Of Cyperusesculentus, An Emergent Plant, “Aquatic Botany”. 6: 13 28.

[5] Okafor, J. C. And Okolo, H. C. (2003). Nutritive Value Of A Mixture Of Tigernut Tubers And Baobab Seeds.J. Sc. Food Agric., 35 : 437- 440.

[6] Anonymous (2005). Tigernut And Health. Http: Www.Tigernut.Com/Salud.Html. Assessed 03/06/13

[7] Aoac (2005). The Official Method Of Analysis. Association Of Official Analytical Chemists. $17^{\text {th }}$ Edition, Washington D.C. Usa.

[8] Munro, A. And Basir, O. (1969). Oxalate In Nigeria Vegetables. Appl. Chem., 12(1): 14- 18

[9] Harbone, J.B. (1973). Phytochemical Methods. Chapman And Hall, New York.

[10] Onwuka, G. I. (2005). Food Analysis And Instrumentation.Naphthali Prints. Surulere, Lagos, Nigeria.Pp 64- 68, 140- 145. 
[11] Mcdonald, P., Edwards, R.A., Greenhalgh, J.F.D. And Morgan, C.A. (1998). Animal Nutrition, $5^{\text {th }}$ Edition ( $3^{\text {rd }}$ Reprint). Longman Scientific And Technical Publishers.

[12] Steel, R.G. D. And Torrie, J. H. (1980). Principles And Procedures Of Statistics. A Biometrical Approach. $2^{\text {nd }}$ Edition. Mcgrawhill Publishers. New York.

[13] Miroslawa, K., Porzuck, H. And Malgorzatoe, K. (1997). Effect Of Heat Treatment On Chemically Modified Proteins Of Legume Seeds. J. Food Chem., 58(3): 221.

[14] Cameron, A.G. (1983). The Science Of Food And Cooking.Edward Arnold Publishers Ltd. London.Pp. 186, 189 And 244.

[15] Hunt, C., Burn, P. And Adamezuk, Z.C. (1987). Proximate Composition And Fat Type Of Popular Take Away Meal. Int. J. Food Sci. And Technol., 22: 669- 675.

[16] Bamgbose, A.M., Eruvbetine, D. And Dada, W. (2003). Utilization Of Tigernut (Cyperusesculentus) In The Diets For Cockerel.

[17] Kumar, N. R. And Reddy, A. N. (1979). Levels Of Phenolic Substances In The Peas Chelated In Cicer Seed. Indian J. Exp. Biol., 17: 114- 116.

[18] Pearson, D. A. (1976). Chemical Analysis Of Foods. $7^{\text {th }}$ Edition. Churchill Livingstone, Edinburgh, London. Pp. $94-125$.

[19] Kay, T., Ogunsola, V. A. And Eka, O.U. (1977). The Prevention Of Beany Taste Development And The Elimination Of Bitter Taste In Preparing Soya Bean Food In Rural Community In Nigeria.Samaru Agriculture Newsletter.9:83- 84. 